TM Matthews $\cdot$ RK Duncan $\cdot$ M Zidanic

TH Michael · PA Fuchs

\title{
Cloning and characterization of SK2 channel from chicken short hair cells
}

Received: 29 May 2004/ Revised: 7 December 2004/ Accepted: 18 December 2004/Published online: 3 May 2005

(C) Springer-Verlag 2005

\begin{abstract}
In the inner ear of birds, as in mammals, reptiles and amphibians, acetylcholine released from efferent neurons inhibits hair cells via activation of an apamin-sensitive, calcium-dependent potassium current. The particular potassium channel involved in avian hair cell inhibition is unknown. In this study, we cloned a small-conductance, calcium-sensitive potassium channel (gSK2) from a chicken cochlear library. Using RT-PCR, we demonstrated the presence of gSK 2 mRNA in cochlear hair cells. Electrophysiological studies on transfected HEK293 cells showed that gSK2 channels have a conductance of approximately $16 \mathrm{pS}$ and a halfmaximal calcium activation concentration of $0.74 \pm 0.17 \mu \mathrm{M}$. The expressed channels were blocked by apamin $\left(\mathrm{IC}_{50}=73.3 \pm 5.0 \mathrm{pM}\right)$ and d-tubocurarine $\left(\mathrm{IC}_{50}=7.6 \pm 1.0 \mu \mathrm{M}\right)$, but were insensitive to charybdo-
\end{abstract}

\section{T. Matthews}

Department of Biomedical Engineering,

The Center for Hearing Sciences,

Johns Hopkins University School of Medicine,

521 Traylor Building, 720 Rutland Ave.,

Baltimore, MD 21205-2195, USA

R. Duncan

Kresge Hearing Research Institute,

University of Michigan, 4038 KHRI,

1301 E. Ann St.,, Ann Arbor, MI 48109-0506,

USA

T. Michael

Memory Pharmaceuticals Corporation,

100 Philips Parkway, Montvale, NJ 07645, USA

M. Zidanic

Walter Reed Army Institute of Research,

Washington DC 20307-5100, USA

P. Fuchs $(\bowtie)$

Otolaryngology-HNS,

The Center for Hearing Sciences,

Johns Hopkins University School of Medicine,

521 Traylor Building, 720 Rutland Ave.,

Baltimore, MD 21205-2195, USA

E-mail: pfuchs@bme.jhu.edu

Tel.: + 1-410-9553877

Fax: + 1-410-6144748 toxin. These characteristics are consistent with those reported for acetylcholine-induced potassium currents of isolated chicken hair cells, suggesting that gSK2 is involved in efferent inhibition of chicken inner ear. These findings imply that the molecular mechanisms of inhibition are conserved in hair cells of all vertebrates.

Keywords Chicken - Efferent inhibition - Hair cells · Patch-clamp techniques - Small-conductance calciumsensitive potassium channels

Abbreviations BK: Large-conductance, calciumsensitive potassium channel $\cdot d-T C$ : d-tubocurarine IK: Intermediate-conductance, calcium-sensitive potassium channel $\cdot$ SK: Small-conductance, calcium-sensitive channel

\section{Introduction}

In contrast to the coiled mammalian cochlea, the avian auditory organ referred to as the basilar papilla is only slightly arced with approximately 10,000 mechanosensory hair cells along its 4-mm length. Though the basilar papilla of birds lacks the characteristic spiral shape of its mammalian equivalent, it is often called a "cochlea" by functional analogy. There is no distinct separation of hair cell types into rows as in the mammalian cochlea; rather, there is a gradient of cell size and shape both along and across the papilla (Hirokawa 1978; Tanaka and Smith 1978). However, as in mammals, there are two functionally defined auditory hair cell types in birds (Hirokawa 1978). The avian tall and short hair cells are comparable to mammalian inner and outer hair cells, respectively. Like their mammalian counterparts, tall and short hair cells have different patterns of innervation. Tall hair cells, like inner hair cells, receive the bulk of the afferent innervation, whereas short hair cells, like outer hair cells, are predominantly innervated by efferent fibers (Hirokawa 1978; Fischer 1992). Some short hair cells 
receive one or two small afferent boutons, like mammalian outer hair cells, but the most inferiorly located short hair cells have no afferent contacts at all (Fischer 1992).

Efferent inhibition of auditory hair cells is mediated by the interaction of acetylcholine receptors and calcium-sensitive potassium channels (Norris and Guth 1974; Guth et al. 1976; Art et al. 1984; Housley and Ashmore 1991; Fuchs and Murrow 1992a; He and Dallos 1999). Efferent neurons from the superior olivary complex release acetylcholine onto the hair cells, triggering calcium influx through nicotinic acetylcholine receptors (nAChRs). This calcium influx activates nearby small-conductance calcium-sensitive potassium (SK) channels and, as potassium flows outward, the corresponding hyperpolarization inhibits the hair cell. This is consistent in mammals (Blanchet et al. 1996; Evans 1996; Nenov et al. 1996b), birds (Fuchs and Murrow 1992a; Yuhas and Fuchs 1999), reptiles (Art et al. 1982, 1984, 1995) and amphibians (Sugai et al. 1992; Smotherman and Narins 1999). While it has been shown that the influx of calcium through acetylcholine channels may be adequate to activate nearby SK channels (Martin and Fuchs 1992), some features of efferent inhibition suggest that internal calcium stores may also be involved (Sridhar et al. 1997; Bobbin 2002).

Currently, there are three known isoforms of SK channels (SK1, SK2 and SK3). In rat, the SK channels are more than $80 \%$ identical (at the amino acid level) across their transmembrane regions and have similar conductance and calcium dependence (Kohler et al. 1996). Nevertheless, while SK1 and SK2 are voltage-independent (Kohler et al. 1996), SK3 channels isolated from rat liver show voltage-dependent inactivation (Barfod et al. 2001). Moreover, of the three isoforms, SK2 channels appear to be the most sensitive to apamin, the bee-venom peptide classically used to identify SK channels, and to d-tubocurarine, a nicotinic acetylcholine receptor antagonist (Kohler et al. 1996; Strobaek et al. 2000; Grunnet et al. 2001). SK 2 channels have been identified in the inner ear of rat (Dulon et al. 1998; Oliver et al. 2000) and mouse (Nie et al. 2004). Moreover, there is pharmacological evidence for SK channels in vestibular hair cells of mammals and birds, as well (Rennie and Correia 1994). The characteristics of the acetylcholine-induced potassium current in chicken short hair cells are consistent with SK channels (Fuchs and Murrow 1992a; Yuhas and Fuchs 1999). A preliminary report suggested the SK 2 gene may be expressed in chicken cochlea (Zidanic et al. 2000), but identification remained incomplete.

In this paper, we provide the characterization of an SK channel expressed in a non-mammalian inner ear organ. Chicken SK2 (gSK2) was cloned from a chicken cochlear cDNA library, and the presence of gSK2 in short hair cells was confirmed by RT-PCR. We expressed cloned gSK2 channels in HEK293 cells and investigated the electrophysiological properties of the channel. The voltage independence, calcium sensitivity and pharmacology of cloned gSK2 channels were consistent with previously reported characteristics of ace- tylcholine-induced inhibitory currents in isolated chicken short hair cells. Thus, we conclude that the gSK2 gene is likely to encode the calcium-sensitive potassium channel involved in cholinergic inhibition of the chicken inner ear.

\section{Methods}

\section{Cloning gSK2 from chicken cochlea cDNA library}

A pair of degenerate primers based on rat sequences (Kohler et al. 1996) were synthesized that would amplify product from SK1, SK2 or SK3. A cDNA library created from chicken cochlea (Jiang et al. 1997) was subject to mass in vivo excision to generate a plasmid cDNA library for use as a template for PCR. After a PCR product of the expected size was obtained with the degenerate primers, specific primers were made from the PCR product and paired with vector primers using a two-round nested PCR strategy. A process of new primer design and amplification was iterated until a fulllength sequence was obtained. A 'touchdown' protocol was employed with specific primers: ten cycles consisting of $30 \mathrm{~s}$ at $94^{\circ} \mathrm{C}, 30 \mathrm{~s}$ at $70-60^{\circ} \mathrm{C}$, changing 1 degree each cycle, $90 \mathrm{~s}$ at $72^{\circ} \mathrm{C}$; then 25 cycles at 94,60 , and $72^{\circ} \mathrm{C}$, followed by $7 \mathrm{~min}$ at $72^{\circ} \mathrm{C}$ for extension. PCR products were sub-cloned into pGEM for automated sequencing, or sequenced directly after extraction from the gel.

Dissection of chicken inner ear and isolation of short hair cells

The care, maintenance, and treatment of animals in these studies followed protocols approved by the Institutional Animal Care and Use Committee of Johns Hopkins University.

\section{Dissection of whole cochlea}

All instruments and dishes were treated with RNAse Erase (Qbiogene), washed with ddH2O, and allowed to dry. Chicks (Gallus gallus), 4-12 days old, were anesthetized with $0.4 \mathrm{cc} 50 \%$ urethane by intramuscular injection and decapitated $10 \mathrm{~min}$ after the injection. The external auditory canal was opened, and the middle-ear cavity exposed. The cochlea was extracted through the oval window and immediately quick-frozen in a microcentrifuge tube on dry ice or placed in a petri dish of RNAse-free saline solution (in mM: $154 \mathrm{NaCl}, 6 \mathrm{KCl}$, $0.1 \mathrm{CaCl}_{2}, 5$ HEPES; pH 7.4). Cochleae were immediately micro-dissected (see below).

\section{Micro-dissection of sensory epithelium and isolation of short hair cells}

The sensory epithelium is the specialized portion of the cochlea that includes the basilar membrane and the 
attached hair cells and supporting cells. No enzymes were used in the micro-dissection of the sensory epithelium or the isolation of short hair cells. The cochlea was pinned to the elastomer (Sylgard) that coated the petri dish. The tegmentum vasculosum was removed with forceps, revealing the sensory epithelium and overlying tectorial membrane. The micro-dissected epithelium was then transferred to a (RNase-free) shallow tissue well filled with RNase-free saline for individual hair cell isolation.

Fine insect pins were used to remove the sensory epithelium from the cochlear duct and from the tectorial membrane. The tectorial membrane was carefully peeled from the epithelium. Some hair cells remained attached to the tectorial membrane and others remained attached to the basilar membrane. Hair cells could be easily pulled from the basilar membrane, but had to be gently and meticulously scraped from the tectorial membrane. Following dissociation from the tectorial membrane, hair cells, supporting cells and epithelial tissue was present in the dissection dish in clumps. Using a pulled micropipette approximately 100-200 microns in diameter, the tissue clumps were mechanically dissociated into single cells by repeated suction and expulsion through the pipette tip. Hundreds of hair cells, free of debris or supporting tissue, could be obtained in dissection, and approximately $50-100$ of these cells were short hair cells. In these experiments, short hair cells were identified visually as having cuticular plates wider than the height of the cell. Overall, cell integrity was maintained: hair bundles were not splayed and there was no blebbing or indication of spilled cytoplasm contents.

Single cells were sucked into a pipette of 30-micron tip, tip-filled with RNase-free saline and back-filled with PicoPure RNA extraction buffer (Arcturus). Cells were immediately lysed upon contact with extraction buffer, and the extraction buffer preserved RNA at room temperature up to $1 \mathrm{~h}$. Once the desired number of cells was acquired, the pipette tip was broken off into a microcentrifuge tube filled with $100 \mu$ RNA extraction buffer. Fluid remaining in the pipette was gently blown into a microcentrifuge tube via RNase-free tubing attached to a $5 \mathrm{ml}$ syringe. Between 40 and 100 intact short hair cells were collected in a single pipette for each experiment. Care was taken to avoid drawing other cellular debris into the micropipette. Dissection fluid from the cell collection dish was analyzed in the same manner as the collected hair cells (see below) to verify that there was no contamination from spilled cell contents or debris in the dissociation bath.

\section{Short Hair Cell RT-PCR analysis}

Total RNA was extracted from hair cells solubilized in $100 \mu \mathrm{l}$ extraction buffer (Arcturus) using the PicoPure RNA Extraction Kit (Arcturus). DNA contamination was minimized by a 15-min incubation with DNase (Qiagen) according to Arcturus protocols. Reverse transcription (RT) of RNA proceeded immediately after extraction. RT was conducted with SuperScript II reverse transcriptase (Invitrogen) using oligo (dT) primers in a six-step protocol according to manufacturer's instructions. Following the RT reaction, products were incubated with RNase $\mathrm{H}$ (Invitrogen) for $20 \mathrm{~min}$ at $37^{\circ} \mathrm{C}$.

PCR was conducted with PlatinumTaq DNA Polymerase (Invitrogen) using "touch-down" protocols and reaction mixtures as suggested by the manufacturer. Specific primers spanned the gSK2 gene (GenBank accession number AF079372). The primer sequences were 5'-TGGCGCTTTACGGCCCCGCCGG-3' (forward) and 5'-CCTCCTCCACAGCACCACCAACTTCATCGG-3' (reverse). The primers used spanned the reported mammalian (human) SK2 splice sites (Desai et al. 2000) thereby, reducing the risk of genomic DNA contamination.

The volumes used for each reaction and the approximations of hair cell product per PCR reaction were as follows. Total RNA extracted from collected short hair cells was split equally for RT into a microcentrifuge tube with reverse transcriptase and a microcentrifuge tube without reverse transcriptase (negative control), each with a total volume of $20 \mu \mathrm{l}$. For PCR, $2 \mu \mathrm{l}$ of the RT product was amplified per PCR tube (total volume $50 \mu \mathrm{l})$. PCR products $(10 \mu \mathrm{l}$ per lane) were run on $2 \%$ agarose gels and visualized with ethidium bromide. Fluid from the dissection bath was processed in the same manner, including RT reaction with and without reverse transcriptase.

\section{Transient Expression of gSK2 in HEK293 cells}

Human embryonic kidney (HEK) 293 cells were cultured in growth media in a humidified $5 \% \mathrm{CO}_{2}$ atmosphere at $37^{\circ} \mathrm{C}$. HEK growth medium consisting of high glucose $(4 \mathrm{mM})$ DMEM with $10 \%$ fetal bovine serum, $100 \mu \mathrm{g} / \mathrm{ml}$ penicillin-streptomycin, and an additional $4 \mathrm{mMs}$ L-glutamine was filtered through a 0.2 micron filter and stored at $4{ }^{\circ} \mathrm{C}$. For some cultures, $125 \mu \mathrm{l}$ Plasmocin (Invivogen) and $2.5 \mathrm{ml}$ Fungizone (Invitrogen) was added to $500 \mathrm{ml}$ of stock media. However, because Fungizone can interfere with seal integrity, cells intended for patch clamp experiments were removed from Fungizone-containing media for a minimum of $72 \mathrm{~h}$ before use.

For patch clamp experiments, HEK293 cells were plated on clean glass cover slips on the bottom of $35 \mathrm{~mm}$ petri dishes filled with growth media. gSK2 DNA cloned into the expression vector pcDNA3.1 and an enhanced green fluorescent protein (GFP) vector (Clontech; pEGFPLuc Cat.\#6169-1) were simultaneously transfected into HEK 293 cells using Lipofectamine 2000 (Invitrogen) in a 2:1:1 ratio (gSK2:GFP:Lipofectamine). Four to $12 \mathrm{mg}$ of gSK2 DNA was used per dish. Control cells consisted of cells transfected with only GFP and cells that were not transfected at all. 
Electrophysiology

All experiments were performed at room temperature. For all except single channel recordings, electrophysiological experiments were performed as follows. Outsideout or inside-out membrane patches (Hamill et al. 1981) were excised from gSK2-transfected HEK293 cells 24 to $72 \mathrm{~h}$ after transfection using electrodes measuring 3$6 \mathrm{M} \Omega$, pulled from borosilicate glass (Drummund Scientific) and coated with wax (SWIX). Membrane patches were voltage-clamped with an Axopatch-1D amplifier (Axon Instruments). Recordings were low pass filtered at $5 \mathrm{kHz}$ and digitized at $20 \mathrm{kHz}$ with an ITC-16 computer interface (Instrutech). Recordings were acquired by Pulse/PulseFit software (HEKA) and stored directly onto a Macintosh Iivx computer. For singlechannel recordings, excised inside-out patches were pulled from gSK2-transfected HEK293 cells 24 to $72 \mathrm{~h}$ after transfection using electrodes measuring 5-10 M $\Omega$, pulled from borosilicate glass (Drummund Scientific) and coated with wax (SWIX). Membrane patches were voltage-clamped with an Axopatch 200B amplifier using a CV 203BU headstage (Axon Instruments). Continuous recordings were low pass filtered at $1 \mathrm{kHz}$ with a Bessel filter, digitized at $50 \mathrm{kHz}$ using pClamp software (Axon) and stored directly onto a Pentium III computer. Noise was generally $1-2 \mathrm{pA}$, peak to peak.

The recording electrode solution contained (in $\mathrm{mM}$ ) $10 \mathrm{NaCl}, 142 \mathrm{KCl}, 2 \mathrm{MgCl}_{2}, 0.9 \mathrm{CaCl}_{2}, 1$ EGTA, and 10 HEPES (pH 7.2 with $\mathrm{KOH}$ ). Cells were patched in a $\mathrm{Na}^{+}$Ringer's solution containing (in mM) $140 \mathrm{NaCl}$, $4 \mathrm{KCl}, 2 \mathrm{CaCl}_{2}, 1 \mathrm{MgCl}_{2}$, and 10 HEPES (pH 7.2, adjusted with $\mathrm{NaOH}$ ). For inside-out patch recordings, once a tight seal was obtained in the $\mathrm{Na}^{+}$Ringer's solution, the entire bath solution was exchanged. The bath solutions used for measuring calcium sensitivity contained (in $\mathrm{mM}$ ) $142 \mathrm{KCl}, 5 \mathrm{HEPES}$ and $0.5 \mathrm{MgCl}_{2}$, with free calcium concentrations achieved by buffering with $2 \mathrm{mM}$ of one of three calcium buffers: EGTA for 0 $0.75 \mu \mathrm{M}$ free calcium, dibromo-BAPTA (Molecular Probes, Inc.) for $1-5 \mu \mathrm{M}$ free calcium, or nitrilotriacetic acid for $20-100 \mu \mathrm{M}$ free calcium. Solutions were adjusted to a $\mathrm{pH}$ of 7.2 with $\mathrm{KOH}$. MaxChelator software (Patton et al. 2004) was used to estimate the amount of $\mathrm{CaCl}_{2}$ necessary to achieve the desired free calcium concentration. However, free calcium was also directly determined using a calcium electrode (Microelectrodes, Inc.) calibrated with multiple standard solutions ranging from $0.1 \mu \mathrm{M}$ to $100 \mu \mathrm{M}$ free $\mathrm{Ca}^{2+}$ (CALBUF-2, World Precision Instruments). Stock solutions were frozen for up to 6 months. During the course of these experiments calcium solutions were prepared multiple times and calibrated each time with a new calcium electrode.

For pharmacological experiments, calcium and potassium concentrations were kept constant by using the calibrated calcium bath solutions as described above in the pipette. Apamin, d-tubocurarine and charybdotoxin were diluted in the appropriate bath solutions as indicated. Solution changes and drug applications were applied through full bath exchange. Unless noted otherwise, all chemicals were obtained from Sigma Chemical Co.

\section{Analysis}

\section{Single-channel conductance}

QuB analysis software (http://www.qub.buffalo.edu) was used to analyze single-channel data. Amplitude histograms and probability density functions were generated from recording traces 5-30 s long. Open and closed states were determined using a segmental $k$-means (semi-Markov) method included in the QuB analysis software. Conductance was calculated from the mean amplitude of open and closed states at the recorded holding potential. Separate histograms were generated for each patch recording. In some cases-longer traces - the traces were broken into segments by QuB (because of too many points to compile into a single histogram) and separate histograms were created for each segment. The was no difference in channel conductance among segments from a single patch.

\section{Calcium activation and drug inhibition}

Calcium activation curves were fit by the Hill equation as follows:

$I=\frac{I_{\max }\left[\mathrm{Ca}^{2+}\right]^{n}}{K_{0.5}^{n}+\left[\mathrm{C} a^{2+}\right]^{n}}+\mathrm{C}$

where $I$ is current through the patch, $K_{0.5}$ is the halfmaximal activation concentration of calcium, $\mathrm{n}$ is the Hill coefficient, and $C$ is a constant that compensated for calcium-independent, voltage-independent leak current. All values are reported as the mean \pm s.e.m.

Dose response curves were fit with a modified Hill equation:

$I_{\text {drug }}=\frac{I_{\max }[\mathrm{drug}]^{n}}{\mathrm{IC}_{50}^{n}+[\mathrm{drug}]^{n}}+\mathrm{C}$

where $I_{\text {drug }}$ is the current measured with blocking agents (drug) in the bath, $\mathrm{IC}_{50}$ is the half-maximal block concentration of the blocking agent, and [drug] is the concentration of the blocking agent in the bath.

\section{DNA sequence analysis}

Sequence alignments were performed with the ClustalW protocol (http://www.ebi.ac.uk/clustalw/) for graphical analysis and with DNASIS (Molecular Biology Insights, Inc.) for percent homology calculations. ClustalW was also used to calculate distance matrices for phylogeny. Phylogenies (evolutionary trees) were created with the Drawgram program included in the PHYLIP 3.61 package (http://evolution.gs.washington.edu/phylip.html). 
Sequences used for analysis were obtained from GenBank with accession numbers as follows: human SK1 (NM_002248), human SK2 (NM_021614), human SK3 (NM_002249), human IK (AF033021), mouse SK1 (AF357239), mouse SK2 (AY123778), mouse SK3 (AF357241), mouse IK (NM_008433), rat SK1 (AF000973), rat SK2 (NM_019314), rat SK3 (AF292389), rat IK (AF190458), trout SK2 (AF363729) and trout SK3 (AF363730).

\section{Results}

Screening of chicken cochlear library and cloning of gSK2 gene

A PCR-based strategy was used to identify SK homologues in a chicken (Gallus gallus) cochlear cDNA library. Prior to this study, no chicken SK channel sequence was known, thus we probed a chicken cochlear library using degenerate primers based on a conserved sequence common to SK genes (1-3) published for rat (Kohler et al. 1996). Using these degenerate primers, a 232-bp portion of the gSK2 gene was amplified. To get the complete sequence of the gSK2 gene from the library, subsequent rounds of amplification paired a specific primer based on the partial gSK2 sequence with one matching vector sequence, either $3^{\prime}$ or $5^{\prime}$, of the cDNA insert. In this way, a full-length gSK 2 cDNA was obtained and sequenced. No SK1 or SK3 products were found.

The amino acid sequence of gSK2 (GenBank accession number AF079372) is compared to the rat, human, mouse and trout SK2 sequences in Fig. 1a. The gSK2 gene was 2,237 bp long, coded for an open reading frame of 556 amino acids orthologous to known SK2 (rat, human, mouse and trout) sequences, and contained the functional domains previously described for SK channels (Kohler et al. 1996; Xia et al. 1998). The functional domains include six transmembrane segments, a pore region characteristic of the potassium channel family, and a calmodulin-binding domain. In Fig. 1a, amino acids conserved between the species are blocked in black and the functional domains are indicated with lines and asterisks above the sequences. Overall, gSK 2 is most similar to rat $(92.8 \%$ identical at the amino acid level) and most divergent from trout $(83.5 \%$ identical).

In rat, the sequences for SK1, SK 3 and an intermediate conductance channel (IK) have also been reported (Kohler et al. 1996; Neylon et al. 1999), but no other chicken small-conductance, calcium-sensitive channels have been identified. Like SK channels, the IK channel is voltage-insensitive and has a smaller conductance than calcium-sensitive maxi-K channels (Neylon et al. 1999), and is sometimes referred to as SK4. However, unlike SK channels, the IK channel is sensitive to charybdotoxin, is less sensitive to calcium, and has a higher conductance than SK channels (Malik-Hall et al. 2000;
Syme et al. 2000). Across subtype, the SK channels are most similar to each other within their transmembrane regions, so we used this region to compare gSK2 channels to other channels in the SK family. From the endoplasmic reticulum signal to the end of sixth transmembrane region, the gSK2 amino acid sequence was $98.5 \%$ identical to rat SK2, 83.8\% identical to rat SK1, and $89.1 \%$ identical to rat SK3. Within this region, gSK 2 was less than $40 \%$ identical to rat IK.

Two stretches of polyglycine residues found in the mammalian N-termini are missing from the chicken and trout sequences. Also, across species there are several different amino acids in the C-termini of the SK2 genes (beginning at the residue corresponding to gSK2 amino acid 466). For several of these residues, chicken and trout have amino acids in common that differ from the mammalian sequences. To date, no particular function has been ascribed to any of these substitutions; however, they do distinguish the $\mathrm{N}$-terminus sequences of mammalian SK2 genes from mammalian SK1 and SK3 genes. Moreover, all the SK channel isoforms (across type and species) are most divergent from each other in the $\mathrm{N}$ - and C-termini.

A variant of gSK2 was also found. The variant has a three amino acid insert (ARK) in the chicken gene beginning at the location corresponding to rat SK2 amino acid 462. There is no such variant reported for mammalian SK2. These three amino acids are present in the trout SK2 gene (Panofen et al. 2002); however, there has been no trout SK2 sequence reported without the ARK sequence, so it appears that ARK is not a splice alternative version of the trout gene. Interestingly, the rat, human and mouse SK1 genes have a similar stretch of amino acids (AQK) corresponding to the location of ARK in trout SK2 and in the gSK2 variant.

The phylogeny of known chicken, human, rat, mouse, and trout SK proteins (including IK) showed that, as expected, each SK isoform has a common node shared among the species (Fig. 1b). The SK1 and SK2 proteins seem to have a closer evolutionary relationship to each other than to SK3 because the SK1 and SK2 protein branches split from a common node. According to this phylogeny, gSK2 is more closely related to the other SK2 genes than any other SK isoform. However, among the SK2 proteins, the mammalian SK2 genes have the closest relationships to each other. Moreover, trout seems to have a closer relationship to the mammal group than the chicken, as evidenced by the split in the branch that separates gSK2 from the other SK2 species.

\section{gSK2 expression in chicken short hair cells}

The expression of gSK2 in chicken short hair cells was analyzed by RT-PCR. Figure 2 shows the results of RTPCR on isolated short hair cells. Chicken $\beta$-actin and chicken nicotinic acetylcholine receptor subunit $\alpha 9$ were used as positive controls. The $\alpha 9$ gene encodes for a subunit in the nicotinic acetylcholine receptor associated 
Fig. 1 a,b Sequence comparison and phylogeny of gSK2. a Amino Acid sequences of chicken (gSK2), rat (rSK2), human (hSK2), mouse (mSK2) and trout (tSK2) for SK2 aligned using the ClustalW protocol. The endoplasmic reticulum retention signal (ERs), pore region and transmembrane regions ( $\mathrm{S} 1$ S6) are single overlined (Kohler et al. 1996). The entire purported calmodulin binding domain (CAMBD) is double overlined (Xia et al. 1998), and two residues determined to be crucial for constitutive binding of calmodulin are noted with an asterisk (*) (Lee et al. 2003). The two residues involved in both apamin and dtubocurarine block are noted with a plus $(+)$ (Ishii et al. 1997). Residues conserved among all the gSK2 sequences are shaded in black. Residue numbers for the sequences are given on the left side. b Distance matrices were computed for the protein sequences of chicken (g), human (h), mouse (r), rat (r), and trout (t) for SK and IK and were used to create a phylogeny tree. The perpendicular intersection of a line and bracket (node) indicates common ancestry. Each of the SK isoforms splits off into an outgroup from an isoform-specific node. Note that gSK2 and the other SK2 proteins share a common node but that the SK2 bracket splits once more putting human, mouse, rat and trout SK2 in a different subgroup from chicken
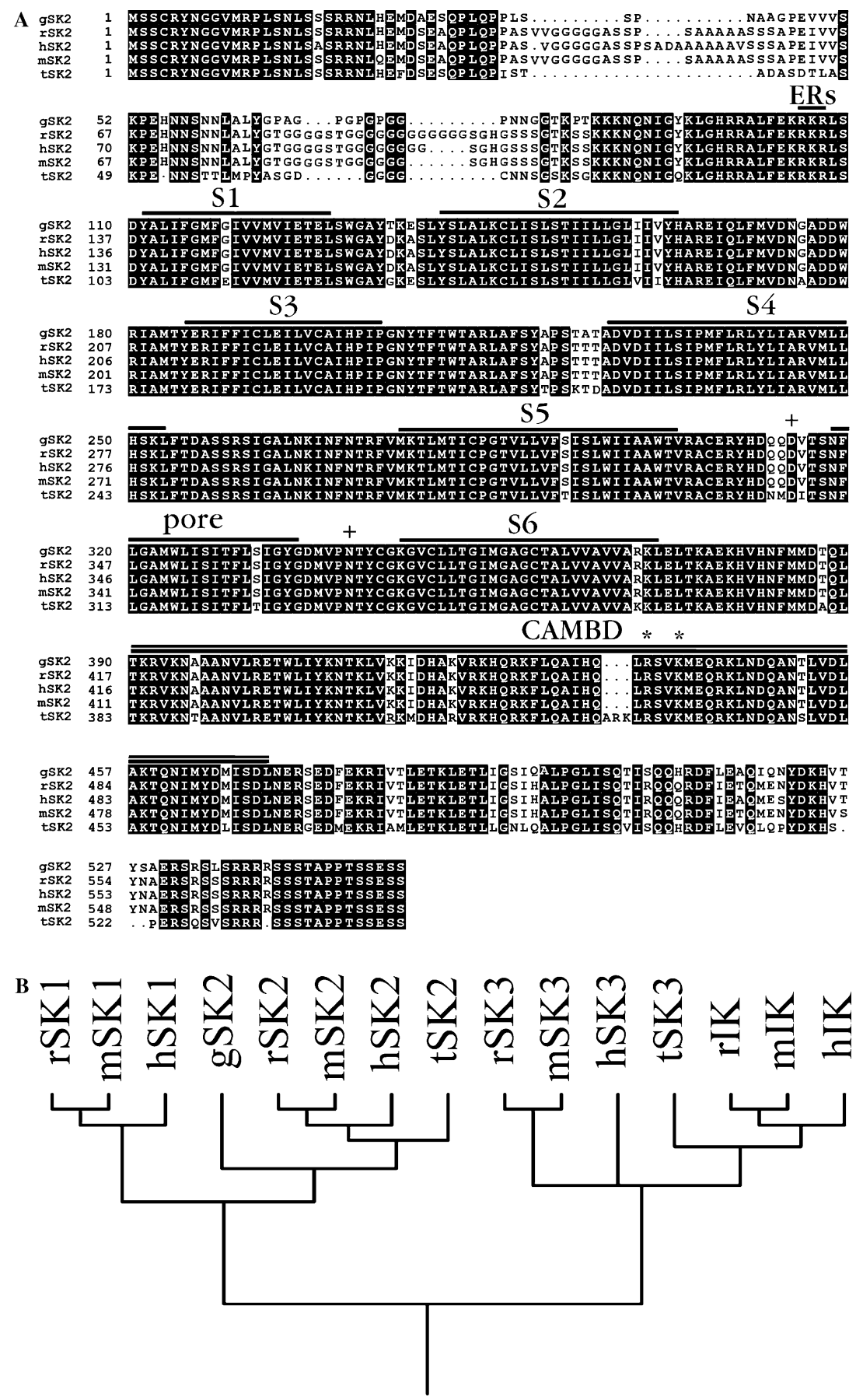

with efferent inhibition of hair cells (Elgoyhen et al. 1994; Hiel et al. 2000). The $\alpha 9$ protein is present in hair cells in smaller quantities than $\beta$-actin and was used as a more stringent positive control. $\beta$-actin was verified according to size and $\alpha 9$ was verified by sequencing.

Using specific gSK2 primers spanning the six transmembrane regions and the proximal portion of the Cterminus, a fragment of the expected size (1483 bp) was amplified from chicken short hair cells (Fig. 2). The results shown in Fig. 2 are from a collection of 50 short hair cells. Calculation of dilution factors suggests that the product of less than three hair cells was amplified in this figure. The fragment was extracted from the gel and sequencing confirmed that it was gSK2. Fluid from the hair cell collection bath was also tested and yielded no gSK2, $\beta$-actin or $\alpha 9$ products (data not shown).

Electrophysiological characterization of gSK2

\section{Conductance and current-voltage relationship}

For analysis of channel function, full-length (including the ARK sequence) gSK2 was co-expressed in HEK293 


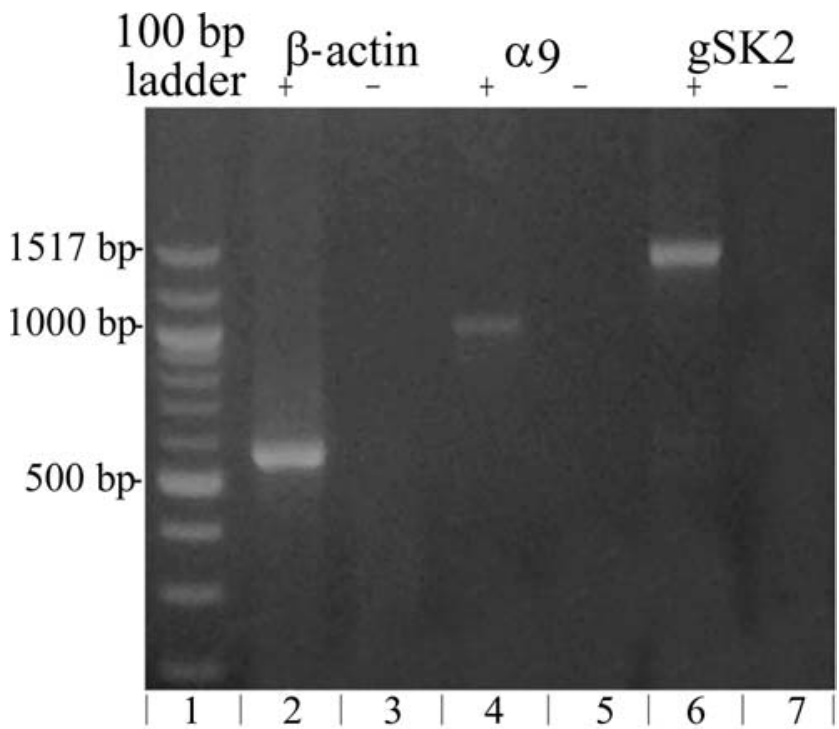

Fig. 2 gSK 2 mRNA in chicken short hair cells. RT-PCR product from isolated hair cells visualized on $2 \%$ agarose gel stained with ethidium bromide. Products from $\alpha 9$ and SK 2 lanes were extracted and sequenced for verification. $\beta$-actin was verified by size. Lane 1:100 bp DNA ladder; lane 2: $\beta$-actin (570 bp); lane 3: $\beta$-actin negative RT control; lane 4: $\alpha 9$ (990 bp); lane 5: $\alpha 9$ negative RT control; lane 6: gSK2 (1,483 bp); lane 7: gSK2 negative RT control. Fluid from the hair cell collection dish was also tested and no bands were seen (Data not shown)

cells with enhanced green fluorescent protein (GFP). Only cells positive for GFP were used for recording. Using an inside-out patch configuration, the cytoplasmic portion of excised membrane was exposed to the recording bath solutions. Pipette and bath potassium concentrations were the same $(142 \mathrm{mM})$ such that inward current was maximized and the reversal potential for potassium was $0 \mathrm{mV}$.

Single-channel recordings from excised inside-out patches showed channels with characteristically small conductance. The recordings in Fig. 3a show partial traces from a typical inside-out patch in which singlechannel activity could be resolved when the patch was voltage-clamped to $-100 \mathrm{mV}$ in a $0.2 \mu \mathrm{M}$-calcium bath (upper trace) and a $2.0 \mu \mathrm{M}$-calcium bath (lower trace). In $0.2 \mu \mathrm{M}$-calcium, channel openings are sporadic and easily distinguishable. In $2.0 \mu \mathrm{M}$-calcium, channel openings occur much more frequently such that channel closings are rarely observed, and no channel activity was observed in nominally $0 \mu \mathrm{M}$ calcium baths. This was to be expected from a channel gated by calcium. An amplitude histogram for this patch is shown in Fig. 3b. Histograms for patches were made from 5-30-s long traces acquired in low calcium baths in which single-channel openings and closings could be clearly determined. Amplitude histograms were generated from 12 excised patches from different cells. The average single-channel conductance calculated from currents in the patches was $16.3 \pm 1.1 \mathrm{pS}$. Conductance of single-channels ranged from approxi-
A

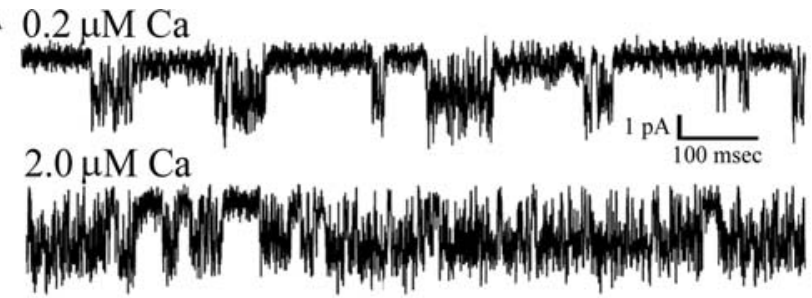

B

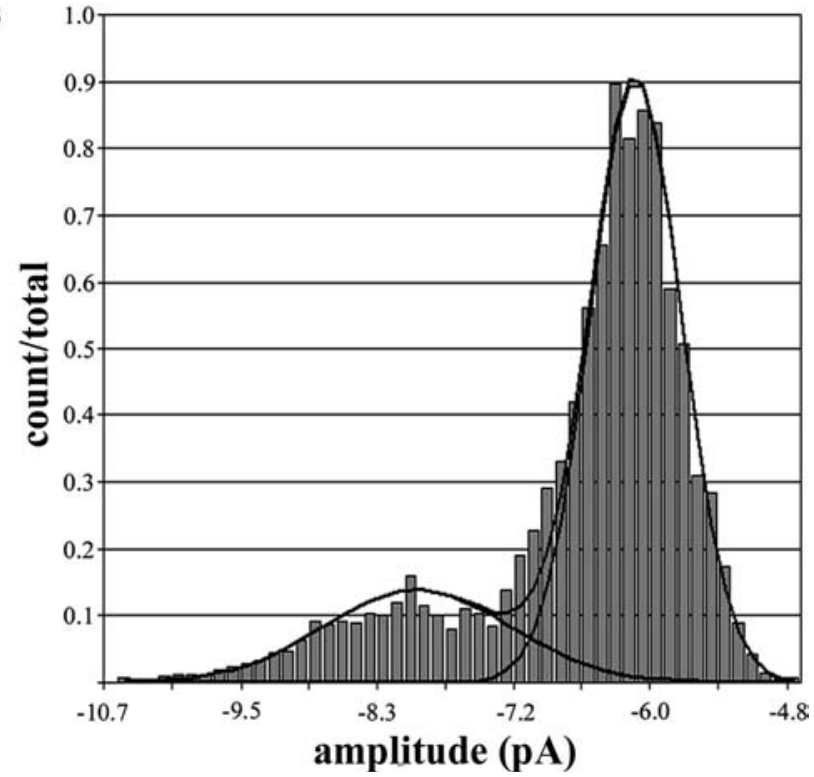

Fig. 3 a,b Single-channel conductance of gSK2. a Representative 1-s traces of an inside-out patch from gSK2-transfected HEK293 cell in which single-channel openings could be observed. With equimolar potassium in the bath and pipette, the upper trace is a recording of patch response to $0.2 \mu \mathrm{M}$ calcium and the lower trace is a recording of patch response in $2.0 \mu \mathrm{M}$ calcium. The patch was voltage clamped to $-100 \mathrm{mV}$ and channel openings are downward deflections. b Amplitude histogram of 10-s recording of which the upper $(0.2 \mu \mathrm{M}$ calcium $)$ trace from $\mathbf{a}$ is a part. Black lines overlying the histogram indicate the probability density function generated for the recording. The mean amplitudes were taken as the current level of the open $(-8.04 \mathrm{pA})$ and closed $(-6.17 \mathrm{pA})$ states. The holding potential of this excised patch was $-100 \mathrm{mV}$, and so the conductance of the channel shown here was $18.7 \mathrm{pS}$

mately 11 to $20 \mathrm{pS}$ in individual patches from separate cells. These numbers are consistent with previous reports of an approximately $14 \mathrm{pS}$ single channel conductance for the acetylcholine-induced outward current in isolated chicken short hair cells (Yuhas and Fuchs 1999), and with cloned SK2 channels from other species (Kohler et al. 1996; Jager et al. 2000; Panofen et al. 2002).

\section{Calcium activation}

The defining characteristic of SK channels is their activation by sub-micromolar calcium (Kohler et al. 1996) via constitutive coupling of their cytoplasmic domains with calmodulin (Xia et al. 1998; Bruening-Wright et al. 2002). We investigated the calcium activation of gSK2 

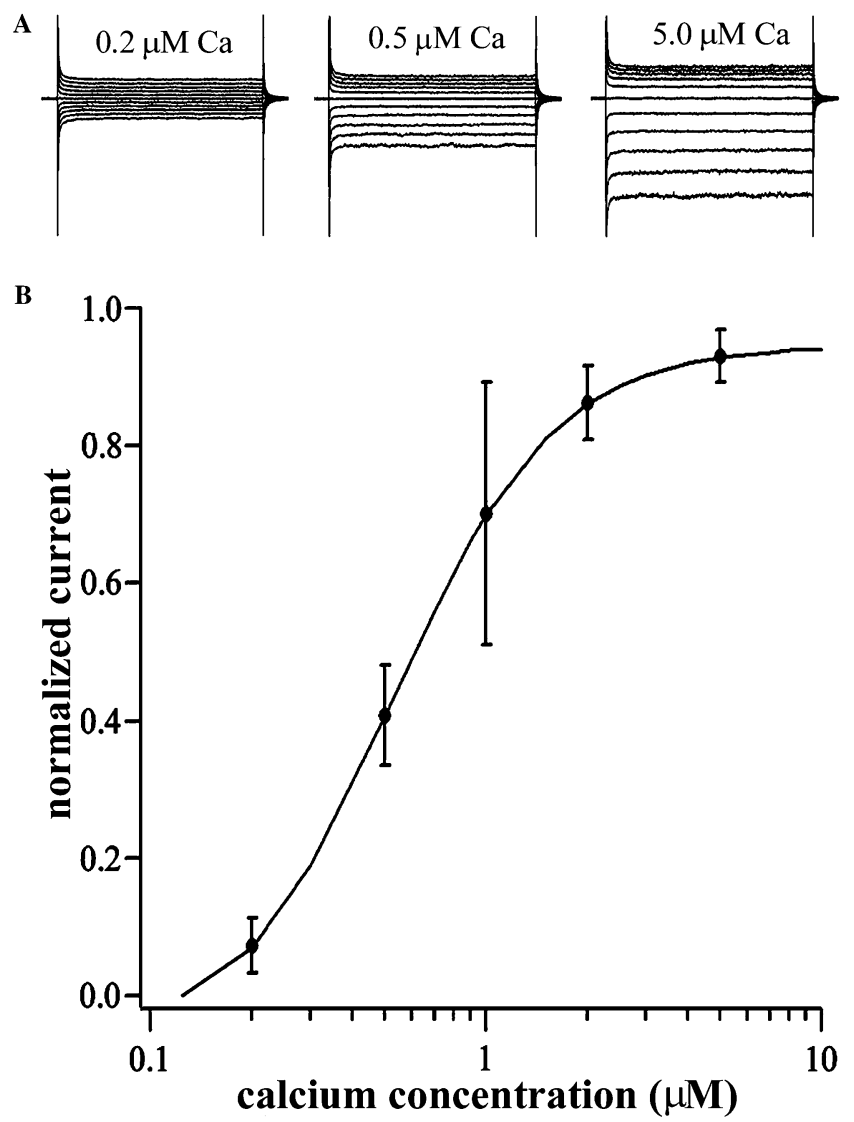

Fig. 4 a,b Calcium activation of gSK2. a Typical current traces from an inside-out patch. An inside-out patch from a gSK2transfected HEK293 cell was voltage clamped in equimolar potassium from $-100 \mathrm{mV}$ to $+100 \mathrm{mV}$ in $500 \mathrm{~ms}$ steps exposed to $0.2,0.5$ and $5 \mu \mathrm{M}$ calcium solutions. b Summary of gSK2 response to calcium. Inside-out patches of gSK2-transfected HEK cells $(N=9)$ were exposed to bath solutions of calcium concentrations ranging from $0.2 \mu \mathrm{M}$ to $5 \mu \mathrm{M}$ at a holding potential of $-80 \mathrm{mV}$. Data was fitted into Hill equation solid line. Fit parameters: $K_{0.5}=0.74 \pm 0.17 \mu \mathrm{M}$ and $n=3.3 \pm 1.8$. Error bars indicate s.e.m

channels using inside-out patches in symmetrical potassium solutions. The patches were exposed to calcium concentrations from $0.2 \mu \mathrm{M}$ to $5 \mu \mathrm{M}$. Figure $4 \mathrm{a}$ shows traces from a typical patch in $0.2,0.5$ and $5 \mu \mathrm{M}$ calcium when voltage was stepped from $-100 \mathrm{mV}$ to $+100 \mathrm{mV}$. gSK2 channels were highly sensitive to calcium concentration, and current through the channels increased with increasing calcium (Fig. 4a,b).

To compute the calcium sensitivity of gSK 2 channels, patches were voltage-clamped to $-80 \mathrm{mV}$ and steady state currents were recorded in increasing calcium concentrations. Normalized currents from nine cells were averaged and fitted into the Hill equation. Half-maximal activation calcium concentration $\left(\mathrm{K}_{0.5}\right)$ was calculated as $0.74 \pm 0.17 \mu \mathrm{M}$. When used to analyze calcium-gated channels, the Hill coefficient $n$ typically is interpreted as the number of calcium ions required to open a calciumsensitive channel. In our experiments, $n$ was $3.3 \pm 1.8$. Both $\mathrm{K}_{0.5}$ and $n$ values for gSK2 were within the range of values previously reported for rat (Kohler et al. 1996; Xia et al. 1998), human (Jager et al. 2000; Pedarzani et al. 2001) and trout (Panofen et al. 2002) SK2 channels. No calcium-sensitive potassium currents could be recorded from non-transfected HEK cells, or HEK cells transfected with only GFP.

\section{Inward rectification}

We characterized the biophysical properties of cloned gSK2 channels over a wide range of membrane potentials. In equimolar potassium, inside-out patches were held at $0 \mathrm{mV}$ and were voltage clamped from $-100 \mathrm{mV}$ to $+100 \mathrm{mV}$ in $500 \mathrm{~ms}$ steps. The current-voltage relationship of a typical patch in various calcium concentrations is shown in Fig. 5a. Current through the patch changed direction at $0 \mathrm{mV}$ (in equimolar potassium solutions). Current through the patches increased with voltage and calcium concentration. The channels in the patches did not show any voltage-dependent gating in baths with moderate and low calcium concentrations, consistent with reports of SK channel voltage independence (Kohler et al. 1996; Desai et al. 2000; Jager et al. 2000; Panofen et al. 2002). At calcium concentrations above $1 \mu \mathrm{M}$, however, current through the patches seemed diminished at more positive voltages. Previous work on rat SK2 channels has confirmed that inward rectification observed in rat SK2 channels is due to a non-specific divalent cation block (Soh and Park 2001; 2002). If true for gSK 2 channels, rectification of gSK 2 currents should be evident at high calcium concentrations. This phenomenon appeared in our recordings (Fig. 4a, 5a) and thus, we investigated the specific effects of high calcium concentrations on gSK2 currents.

Figure $5 \mathrm{~b}$ shows a comparison of currents through gSK2-containing inside-out patches at a positive and a negative holding potential in a range of calcium concentrations. The bath solution and pipette solution contained equal amounts of potassium, thus the driving force for positive and negative voltages was equivalent for potentials equidistant from $0 \mathrm{mV}$. Magnesium concentration was held constant at $0.5 \mathrm{mM}$ and calcium concentration was varied from $0.2 \mu \mathrm{M}$ to $20 \mu \mathrm{M}$. The ratio of current through channels at $-100 \mathrm{mV}$ and $+100 \mathrm{mV}$ was calculated and plotted against calcium concentration (Fig. 5b). Below $2 \mu \mathrm{M}$ calcium, the current rectified very little. However, at concentrations of $2 \mu \mathrm{M}$ calcium and above, the current through channels at $-100 \mathrm{mV}$ was more than twice the current through channels at $+100 \mathrm{mV}$. We conclude that at saturating calcium concentrations, calcium acted as both activator and blocker of gSK2 channels.

\section{Pharmacology of gSK2}

SK channels are subject to block by low concentrations of apamin, and the SK2 isoform has been re- 

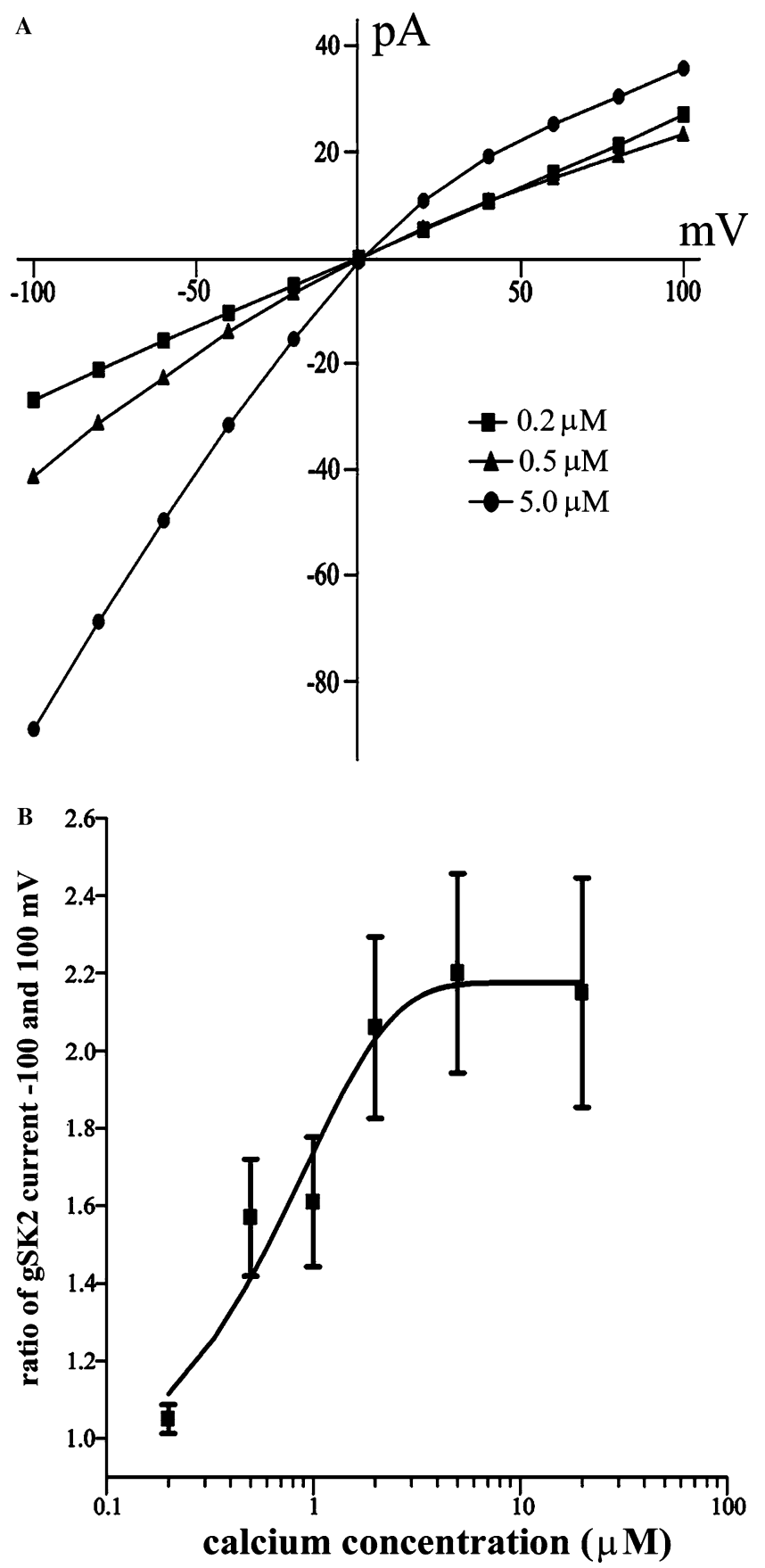

Fig. 5 a,b Rectification of gSK2 current at high voltages. a Current-voltage relationship of typical gSK2-transfected HEK293 cell. Curves compiled from inside-out patch voltageclamped from $-100 \mathrm{mV}$ to $+100 \mathrm{mV}$ in $500 \mathrm{~ms}$ steps while exposed to 0.2 (filled square), 0.5 (filled triangle) and 5 (filled circle) $\mu \mathrm{M}$ calcium solutions. Steady state current is plotted against voltage. Lines have been drawn between points for ease of viewing only. At $0.2 \mu \mathrm{M}$, the increase in current with voltage is a linear function, and at $0.5 \mu \mathrm{M}$ the function remains nearly linear. At $5.0 \mu \mathrm{M}$, the increase in current at holding voltages positive to $E_{K}$ $(=0 \mathrm{mV})$ is less than the increase in current at voltages negative to $E_{K}$. b Inside-out patches from gSK2-transfected HEK293 cells were held at -100 and $+100 \mathrm{mV}$ in calcium solutions ranging from $0.2 \mu \mathrm{M}$ to $20 \mu \mathrm{M}$. The ratio of the average of steady-state currents at $-100 \mathrm{mV}$ and $+100 \mathrm{mV}$ is plotted against calcium concentration $(N=9)$. Error bars are s.e.m. Line is non-linear regression fit of points to Boltzman equation ported as the most sensitive to apamin with halfblocking concentrations in the picomolar range (Kohler et al. 1996; Strobaek et al. 2000; Grunnet et al. 2001). It has been shown that the amino acid residues that determine $\mathrm{SK} 2$ apamin sensitivity in rat are also responsible for SK channel blocking by the plant alkaloid and nicotinic acetylcholine receptor antagonist d-tubocurarine (d-TC) (Ishii et al. 1997). The residues responsible for apamin and d-TC block in rat $\mathrm{SK}$ channels are present in the gSK2 gene (Fig. 1a). Therefore, we tested gSK2 sensitivity to apamin and d-TC.

gSK 2 currents were inhibited by apamin and d-TC (Fig. 6a,b). Several outside-out patches were exposed to multiple apamin concentrations via full bath exchange, and block was recorded as a percentage decrease of maximal current (Fig. 6a). The half blocking concentration of apamin for gSK2 was $73.3 \pm 5.0 \mathrm{pM}$. While greater than $95 \%$ of current could be blocked by high concentrations of apamin, the average block of current by concentrations of apamin greater than $500 \mathrm{pM}$ was $86 \%$. Residual current was likely due to leak or intrinsic HEK293 cell delayed rectifier-type potassium channels (Jiang et al. 2002). The effect of apamin was partially reversed after washing for several minutes. gSK2 currents were inhibited by d-TC less potently than by apamin (Fig. 6b). Several outside-out patches were exposed to multiple d-TC concentrations via full bath exchange, and block was recorded as a percentage decrease of maximal current. The half blocking concentration of d-TC was $7.6 \pm 1.0 \mu \mathrm{M}$. Approximately $20 \%$ residual current remained after saturating block with $\mathrm{d}$ TC. Block by d-TC was completely reversible. Block of gSK 2 by both apamin and d-TC was consistent with that reported for cloned rat (Kohler et al. 1996; Strobaek et al. 2000) and trout (Panofen et al. 2002) channels. However, these antagonists were more potent here than in reports of block of currents presumably carried by SK channels in isolated chicken short hair cells (Yuhas and Fuchs 1999) and human blood cells (Jager et al. 2000).

The pharmacology of the acetylcholine-induced potassium currents in isolated chicken short hair cells has been used to differentiate them from other calciumsensitive potassium currents found in chicken hair cells. In particular, these hair cells have maxi-K or BK (large conductance) channels (Fuchs and Evans 1990) which have a higher conductance than SK channels, are voltage-dependent and are sensitive to charybdotoxin, whereas the acetylcholine-induced potassium currents of short hair cells are not voltage dependent and are insensitive to charybdotoxin (Yuhas and Fuchs 1999). BK channels are blocked by nanomolar concentrations of charybdotoxin (Duwel et al. 2003; Sun et al. 2003). We tested gSK2 sensitivity to charybdotoxin in order to confirm gSK2 as a candidate for the charybdotoxininsensitive acetylcholine-induced potassium channel in short hair cells. Chicken gSK2 channels were not blocked by charybdotoxin up to $1 \mu \mathrm{M}$ (data not shown). 

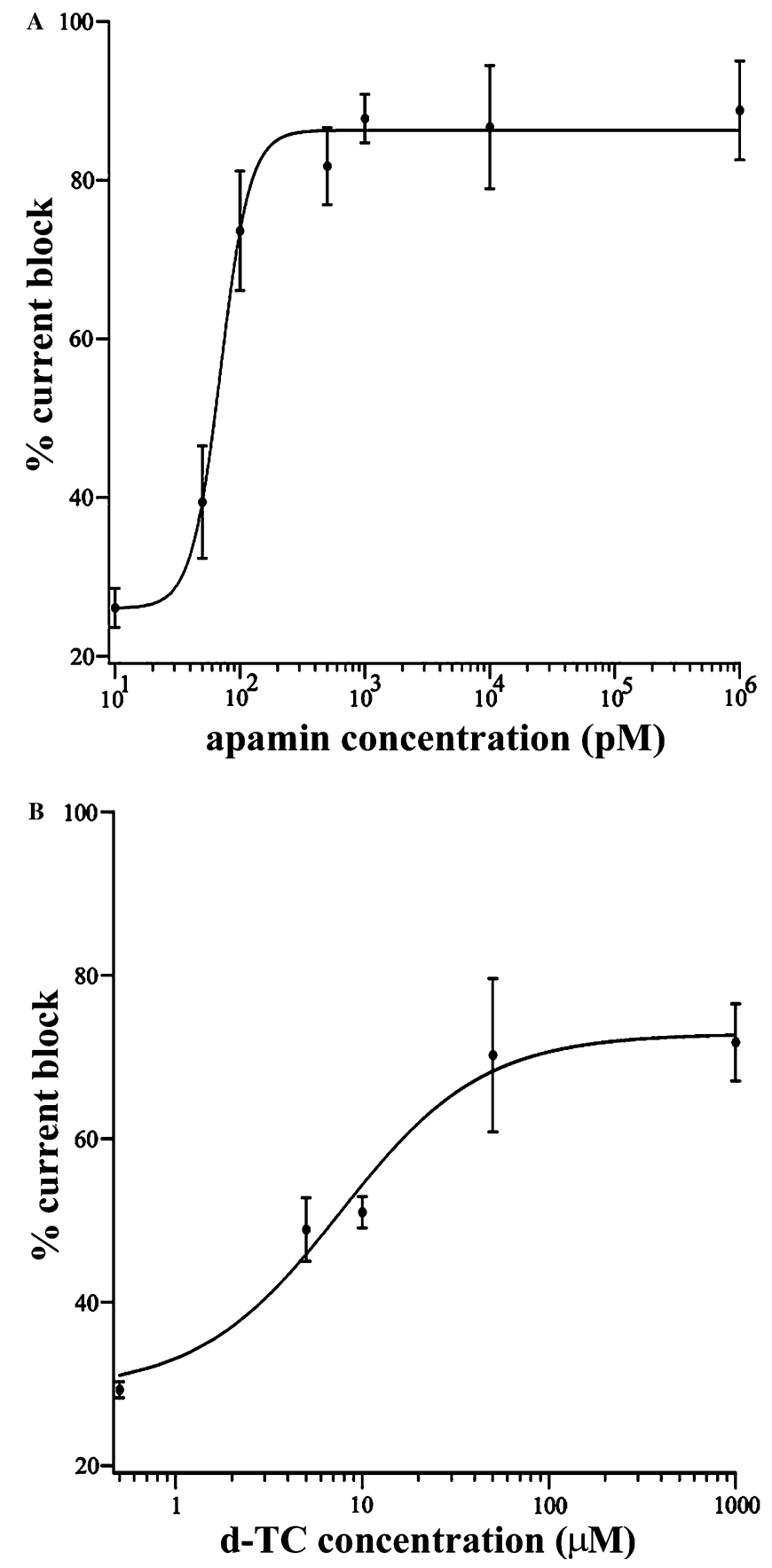

Fig. 6 a,b Apamin and d-tubocurarine block of gSK2 current. a Outside-out patches were exposed to multiple concentrations of apamin in high $\mathrm{K}+$ solutions. Currents were normalized to maximum current through each patch in apamin-free solution, and percent block was determined by the residual current in the presence of apamin. Dose-response curve was fit, Eq. 2, at $-80 \mathrm{mV}$, yielding an $\mathrm{IC}_{50}=70.1 \pm 2.4 \mathrm{pM}$. b Outside-out patches were exposed to multiple concentrations of d-tubocurarine in high $\mathrm{K}+$ solutions. Currents were normalized to maximum current through each patch in d-tubocurarine-free solution, and percent block was determined by the residual current in the presence of $\mathrm{d}$ tubocurarine. Dose-response curve was fit (Eq. 2) at $-80 \mathrm{mV}$, yielding an $\mathrm{IC}_{50}=7.6 \pm 1.0 \mu \mathrm{M}$

\section{Discussion}

In this study we have amplified gSK2 from a chicken cochlear cDNA library, found gSK2 mRNA in chicken short hair cells and characterized cloned gSK2 in HEK 293 cells. gSK 2 channels are activated by calcium $\left(K_{0.5}=0.74 \mu \mathrm{M}\right)$ and have a relatively small single channel conductance of approximately $16 \mathrm{pS}$. Additionally, gSK2 channels are blocked by apamin $\left(\mathrm{IC}_{50}=73 \mathrm{pM}\right)$ and by d-tubocurarine $\left(\mathrm{IC}_{50}=7.6 \mu \mathrm{M}\right)$, and are subject to divalent cation-induced rectification.

The electrophysiological properties of SK2 channels across species are very similar. Even though gSK2 shares the most sequence identity with rat SK2, the calcium sensitivity, apamin block and single channel conductance of cloned SK2 channels from human (Jager et al. 2000), mouse (Ro et al. 2001; Nie et al. 2004) and trout (Panofen et al. 2002), as well as rat (Kohler et al. 1996; Strobaek et al. 2000), are all consistent with gSK2. In cloning and expression studies, SK2 channels have been shown to have half-maximal calcium activation concentration between 0.3 and $0.8 \mu \mathrm{M}$, which encompasses what we report here for chicken. Moreover, the singlechannel conductance reported for SK2 channels ranges from 9 to $20 \mathrm{pS}$, which is also consistent with gSK2. Finally, across species SK 2 channels are half blocked by apamin with $\mathrm{IC}_{50}$ values in the $60-80 \mathrm{pM}$ range like reported here for gSK2. Similar calcium-activation thresholds have been noted for SK1 (Kohler et al. 1996) and SK3 (Barfod et al. 2001) channels, as well. Furthermore, SK channels are all noted for their small ( $<$ $25 \mathrm{pS}$ ) conductance. However, in contrast to SK2, SK1 channels have $\mathrm{IC}_{50}$ values for apamin above $700 \mathrm{pM}$ and SK 3 channels are typically blocked by concentrations intermediate to those of SK2 and SK1 (Kohler et al. 1996; Strobaek et al. 2000; Grunnet et al. 2001).

Our work supports the hypothesis that SK2 channels underlie the cholinergic response of chicken short hair cells. Several studies investigating efferent inhibition of chicken short hair cells have shown that application of acetylcholine to chicken short hair cells results in calcium influx through acetylcholine channels that activates prolonged outward potassium currents (Fuchs and Evans 1990; Fuchs and Murrow 1992b; Martin and Fuchs 1992; Yuhas and Fuchs 1999). The potassium channels that carry these currents are calcium-activated, are sensitive to apamin, are insensitive to charybdotoxin and have a relatively small singlechannel conductance. The involvement of a smallconductance potassium channel in efferent inhibition of hair cells is not unique to chicken. A large body of work has established a similar mechanism in mammals, as well (Housley and Ashmore 1991; Doi and Ohmori 1993; Kakehata et al. 1993; Blanchet et al. 1996; Evans 1996; Nenov et al. 1996a, 1996b; Dulon 
et al. 1998; Oliver et al. 2000). Moreover, the investigations into amphibian (Sugai et al. 1992; Yoshida et al. 1994; Smotherman and Narins 1999) and reptilian (Art et al. 1982; 1984; 1985; 1995; Tucker and Fettiplace 1996) mechanisms of hair cell inhibition support similar conclusions.

The work in mammals has recently been focused on identifying the particular SK channel involved in hair cell inhibition. The results presented here are an exciting companion to the group of investigations supporting the conclusion that SK2 channels are involved in efferent inhibition of mammalian hair cells. The SK2 gene is expressed in outer hair cells of the rat cochlea as shown by RT-PCR and in situ hybridization (Dulon et al. 1998; Oliver et al. 2000). Through functional expression of cloned rat SK2 channels in oocytes and companion studies on isolated outer hair cells, Oliver and colleagues (2000) concluded that, not only are SK2 channels the potassium channels of rat efferent inhibition, but also SK2 channel kinetics determine the kinetics of synaptic inhibition of outer hair cells. Additionally, the SK2 channel has been cloned from mouse cochlea and characterized (Nie et al. 2004). In those experiments, HEK293 cells expressing cloned mouse SK2 channels and mouse $\alpha 9 / \alpha 10$ acetylcholine receptors (found in mouse hair cells) were exposed to acetylcholine. Calcium influx through the expressed $\alpha 9 / \alpha 10$ receptors activated the expressed SK2 channels implying that the combination of these two channels in mouse hair cells may support efferent inhibition in mouse cochlea.

The SK channel isoforms (SK1, SK2 and SK3) are highly homologous across species, particularly within a given subtype. Across the core region, the subtypes are $80 \%$ identical at the amino acid level and within subtypes the identity across species is as high as $95 \%$. Thus, the existence of the chicken ARK splice variant is intriguing. No spliced alternative or stretch of amino acids corresponding to the chicken variant has been reported for any mammalian SK2 gene. However, an identical stretch of amino acids is present in the full trout SK2 gene at a corresponding location (Fig. 1a) and a similar stretch of amino acids (AQK) is present in the reported SK 1 genes (rat, human, and mouse). These ARK/AQK sequences are located within the calmodulin-binding domain. SK channel calcium sensitivity is acquired via its constitutive binding with calmodulin (Xia et al. 1998). Site-directed mutagenesis studies suggest that residues downstream from the ARK/AQK location in particular (Lee et al. 2003) and an upstream helical region in general (Wissmann et al. 2002) are important in calmodulin binding, but no particular role has been attributed to the amino acids corresponding to the location of the ARK/AQK insert. Moreover, even though particular SK channel subtypes have this (ARK/AQK) insert in their calmodulin-binding domain, the calcium sensitivity among SK channels does not vary much across type or species, implying that these residues may not be particularly important in SK-calmodulin binding. The significance of these residues, if any, remains to be found.
Efferent inhibition of hair cells is the latest addition to the litany of roles for SK channels. SK channels have been implicated in after-hyperpolarization of hippocampal neurons (Lancaster et al. 1991; Beck et al. 1997) and sympathetic ganglion cells (Hosseini et al. 2001), spike-frequency adaptation (Engel et al. 1999; Hallworth et al. 2003), changes in membrane permeability during liver injury (Barfod et al. 2001), Jurkat T-cell homeostasis (Desai et al. 2000), and lower bowel function (Klemm and Lang 2002; Herrera et al. 2003; Piotrowska et al. 2003). In the peripheral auditory system, SK channels are surprisingly consistent in function and isoform expression (SK2) across species, despite structural differences in auditory organs. SK channels have now been implicated in efferent inhibition of the inner ear in mammals, birds, amphibians and reptiles. Moreover, the SK2 channel, in particular, has now been identified in auditory hair cells of rat and chicken, as well as in the mouse cochlea. Such highly conserved use of the SK2 channel in auditory systems across species highlights a common and irreplaceable mechanism of activation and gating in peripheral auditory processing.

Acknowledgements This work was supported by an NIDCD DC01508, Research Core Grants P30 DC05211 and P30 DCO5188, Training Grant T 32 DC00023 and funding from The Whitaker Foundation. These experiments comply with the "Principles of animal care," publication No. 86-23, revised in 1985, of the National Institute of Health.

\section{References}

Art JJ, Crawford AC, Fettiplace R, Fuchs PA (1982) Efferent regulation of hair cells in the turtle cochlea. Proc R Soc Lond B Biol Sci 216:377-384

Art JJ, Fettiplace R, Fuchs PA (1984) Synaptic hyperpolarization and inhibition of turtle cochlear hair cells. J Physiol 356:525550

Art JJ, Crawford AC, Fettiplace R, Fuchs PA (1985) Efferent modulation of hair cell tuning in the cochlea of the turtle. J Physiol 360:397-421

Art JJ, Wu YC, Fettiplace R (1995) The calcium-activated potassium channels of turtle hair cells. J Gen Physiol 105:49-72

Barfod ET, Moore AL, Lidofsky SD (2001) Cloning and functional expression of a liver isoform of the small conductance $\mathrm{Ca} 2+$ activated $\mathrm{K}+$ channel SK3. Am J Physiol Cell Physiol 280:C836-842

Beck H, Clusmann H, Kral T, Schramm J, Heinemann U, Elger CE (1997) Potassium currents in acutely isolated human hippocampal dentate granule cells. J Physiol 498(Pt 1):73-85

Blanchet C, Erostegui C, Sugasawa M, Dulon D (1996) Acetylcholine-induced potassium current of guinea pig outer hair cells: its dependence on a calcium influx through nicotinic-like receptors. J Neurosci 16:2574-2584

Bobbin RP (2002) Caffeine and ryanodine demonstrate a role for the ryanodine receptor in the organ of Corti. Hear Res 174:172182

Bruening-Wright A, Schumacher MA, Adelman JP, Maylie J (2002) Localization of the activation gate for small conductance $\mathrm{Ca} 2+$ - activated $\mathrm{K}+$ channels. J Neurosci 22:6499-6506

Desai R, Peretz A, Idelson H, Lazarovici P, Attali B (2000) Ca2 + . activated $\mathrm{K}+$ channels in human leukemic Jurkat $\mathrm{T}$ cells. Molecular cloning, biochemical and functional characterization. J Biol Chem 275:39954-39963 
Doi T, Ohmori H (1993) Acetylcholine increases intracellular $\mathrm{Ca} 2+$ concentration and hyperpolarizes the guinea-pig outer hair cell. Hear Res 67:179-188

Dulon D, Luo L, Zhang C, Ryan AF (1998) Expression of smallconductance calcium-activated potassium channels (SK) in outer hair cells of the rat cochlea. Eur J Neurosci 10:907-915

Duwel P, Jungling E, Westhofen M, Luckhoff A (2003) Potassium currents in vestibular type II hair cells activated by hydrostatic pressure. Neuroscience 116:963-972

Elgoyhen AB, Johnson DS, Boulter J, Vetter DE, Heinemann S (1994) Alpha 9: an acetylcholine receptor with novel pharmacological properties expressed in rat cochlear hair cells. Cell 79:705-715

Engel J, Schultens HA, Schild D (1999) Small conductance potassium channels cause an activity-dependent spike frequency adaptation and make the transfer function of neurons logarithmic. Biophys J 76:1310-1319

Evans MG (1996) Acetylcholine activates two currents in guineapig outer hair cells. J Physiol 491:563-578

Fischer FP (1992) Quantitative analysis of the innervation of the chicken basilar papilla. Hear Res 61:167-178

Fuchs PA, Evans MG (1990) Potassium currents in hair cells isolated from the cochlea of the chick. J Physiol 429:529-551

Fuchs PA, Murrow BW (1992a) Cholinergic inhibition of short (outer) hair cells of the chick's cochlea. J Neurosci 12:800-809

Fuchs PA, Murrow BW (1992b) A novel cholinergic receptor mediates inhibition of chick cochlear hair cells. Proc R Soc Lond B Biol Sci 248:35-40

Grunnet M, Jensen BS, Olesen SP, Klaerke DA (2001) Apamin interacts with all subtypes of cloned small-conductance Ca2 + activated K + channels. Pflugers Arch 441:544-550

Guth PS, Norris CH, Bobbin RP (1976) The pharmacology of transmission in the peripheral auditory system. Pharmacol Rev 28:95-125

Hallworth NE, Wilson CJ, Bevan MD (2003) Apamin-sensitive small conductance calcium-activated potassium channels, through their selective coupling to voltage-gated calcium channels, are critical determinants of the precision, pace, and pattern of action potential generation in rat subthalamic nucleus neurons in vitro. J Neurosci 23:7525-7542

Hamill OP, Marty A, Neher E, Sakmann B, Sigworth FJ (1981) Improved patch-clamp techniques for high-resolution current recording from cells and cell-free membrane patches. Pflugers Arch 391:85-100

He DZ, Dallos P (1999) Development of acetylcholine-induced responses in neonatal gerbil outer hair cells. J Neurophysiol $81: 1162-1170$

Herrera GM, Pozo MJ, Zvara P, Petkov GV, Bond CT, Adelman JP, Nelson MT (2003) Urinary bladder instability induced by selective suppression of the murine small conductance calciumactivated potassium (SK3) channel. J Physiol 551:893-903

Hiel H, Luebke AE, Fuchs PA (2000) Cloning and expression of the alpha9 nicotinic acetylcholine receptor subunit in cochlear hair cells of the chick. Brain Res 858:215-225

Hirokawa N (1978) The ultrastructure of the basilar papilla of the chick. J Comp Neurol 181:361-374

Hosseini R, Benton DC, Dunn PM, Jenkinson DH, Moss GW (2001) SK3 is an important component of $\mathrm{K}(+)$ channels mediating the afterhyperpolarization in cultured rat SCG neurones. J Physiol 535:323-334

Housley GD, Ashmore JF (1991) Direct measurement of the action of acetylcholine on isolated outer hair cells of the guinea pig cochlea. Proc R Soc Lond B Biol Sci 244:161-167

Ishii TM, Maylie J, Adelman JP (1997) Determinants of apamin and d-tubocurarine block in SK potassium channels. J Biol Chem 272:23195-23200

Jager H, Adelman JP, Grissmer S (2000) SK2 encodes the apaminsensitive $\mathrm{Ca}(2+)$ - activated $\mathrm{K}(+)$ channels in the human leukemic T cell line, Jurkat. FEBS Lett 469:196-202

Jiang GJ, Zidanic M, Michaels RL, Michael TH, Griguer C, Fuchs PA (1997) CSlo encodes calcium-activated potassium channels in the chick's cochlea. Proc R Soc Lond B Biol Sci 264:731-737
Jiang B, Sun X, Cao K, Wang R (2002) Endogenous Kv channels in human embryonic kidney (HEK-293) cells. Mol Cell Biochem 238:69-79

Kakehata S, Nakagawa T, Takasaka T, Akaike N (1993) Cellular mechanism of acetylcholine-induced response in dissociated outer hair cells of guinea-pig cochlea. J Physiol 463:227-244

Klemm MF, Lang RJ (2002) Distribution of Ca2 + - activated K + channel (SK2 and SK3) immunoreactivity in intestinal smooth muscles of the guinea-pig. Clin Exp Pharmacol Physiol 29:18-25

Kohler M, Hirschberg B, Bond CT, Kinzie JM, Marrion NV, Maylie J, Adelman JP (1996) Small-conductance, calciumactivated potassium channels from mammalian brain. Science 273:1709-1714

Lancaster B, Nicoll RA, Perkel DJ (1991) Calcium activates two types of potassium channels in rat hippocampal neurons in culture. J Neurosci 11:23-30

Lee WS, Ngo-Anh TJ, Bruening-Wright A, Maylie J, Adelman JP (2003) Small conductance Ca2 + - activated K + channels and calmodulin:cell surface expression and gating. J Biol Chem 278:25940-25946

Malik-Hall M, Ganellin CR, Galanakis D, Jenkinson DH (2000) Compounds that block both intermediate-conductance (IK(Ca)) and small-conductance (SK $(\mathrm{Ca})$ ) calcium-activated potassium channels. Br J Pharmacol 129:1431-1438

Martin AR, Fuchs PA (1992) The dependence of calcium-activated potassium currents on membrane potential. Proc R Soc Lond B Biol Sci 250:71-76

Nenov AP, Norris C, Bobbin RP (1996a) Acetylcholine response in guinea pig outer hair cells. I. properties of the response. Hear Res 101:132-148

Nenov AP, Norris C, Bobbin RP (1996b) Acetylcholine response in guinea pig outer hair cells. II. Activation of a small conductance $\mathrm{Ca}(2+)$-activated K + channel. Hear Res 101:149-72

Neylon CB, Lang RJ, Fu Y, Bobik A, Reinhart PH (1999) Molecular cloning and characterization of the intermediateconductance $\mathrm{Ca}(2+)$ - activated $\mathrm{K}(+)$ channel in vascular smooth muscle: relationship between $\mathrm{K}(\mathrm{Ca})$ channel diversity and smooth muscle cell function. Circ Res 85:e33-e43

Nie L, Song H, Cheng M, Chiamvimonvat N, Beisel KW, Yamoah EN, Vazquez AE (2004) Cloning and expression of a small conductance $\mathrm{Ca} 2+$-activated $\mathrm{K}+$ channel from the mouse cochlea: coexpression with alpha9/alpha10 acetylcholine receptors. J Neurophysiol 91:1536-1544

Norris CH, Guth PS (1974) The release of acetylcholine (ACH) by the crossed olivo-cochlear bundle (COCB). Acta Otolaryngol 77:318-326

Oliver D, Klocker N, Schuck J, Baukrowitz T, Ruppersberg JP, Fakler B (2000) Gating of Ca2 + - activated K+ channels controls fast inhibitory synaptic transmission at auditory outer hair cells. Neuron 26:595-601

Panofen F, Piwowarski T, Jeserich G (2002) Small conductance calcium-activated potassium channels of trout CNS: molecular structure, developmental expression, and partial biophysical characterization. Brain Res Mol Brain Res 101:1-11

Patton C, Thompson S, Epel D (2004) Some precautions in using chelators to buffer metals in biological solutions. Cell Calcium 35:427-431

Pedarzani P, Mosbacher J, Rivard A, Cingolani LA, Oliver D, Stocker M, Adelman JP, Fakler B (2001) Control of electrical activity in central neurons by modulating the gating of small conductance $\mathrm{Ca} 2+-$ activated $\mathrm{K}+$ channels. J Biol Chem 276:9762-9769

Piotrowska AP, Solari V, Puri P (2003) Distribution of Ca2+activated $\mathrm{K}$ channels, SK2 and SK3, in the normal and Hirschsprung's disease bowel. J Pediatr Surg 38:978-983

Rennie KJ, Correia MJ (1994) Potassium currents in mammalian and avian isolated type I semicircular canal hair cells. J Neurophysiol 71:317-329

Ro S, Hatton WJ, Koh SD, Horowitz B (2001) Molecular properties of small-conductance $\mathrm{Ca} 2+-$ activated $\mathrm{K}+$ channels expressed in murine colonic smooth muscle. Am J Physiol Gastrointest Liver Physiol 281:G964-G973 
Smotherman MS, Narins PM (1999) Potassium currents in auditory hair cells of the frog basilar papilla. Hear Res 132:117-130

Soh H, Park CS (2001) Inwardly rectifying current-voltage relationship of small-conductance $\mathrm{Ca} 2+-$ activated $\mathrm{K}+$ channels rendered by intracellular divalent cation blockade. Biophys J 80:2207-2215

Soh H, Park CS (2002) Localization of divalent cation-binding site in the pore of a small conductance $\mathrm{ca}(2+)$ - activated $\mathrm{k}(+)$ channel and its role in determining current-voltage relationship. Biophys J 83:2528-2538

Sridhar TS, Brown MC, Sewell WF (1997) Unique postsynaptic signaling at the hair cell efferent synapse permits calcium to evoke changes on two time scales. J Neurosci 17:428-437

Strobaek D, Jorgensen TD, Christophersen P, Ahring PK, Olesen SP (2000) Pharmacological characterization of small-conductance $\mathrm{Ca}(2+)$ - activated $\mathrm{K}(+)$ channels stably expressed in HEK 293 cells. Br J Pharmacol 129:991-999

Sugai T, Yano J, Sugitani M, Ooyama H (1992) Actions of cholinergic agonists and antagonists on the efferent synapse in the frog sacculus. Hear Res 61:56-64

Sun X, Gu XQ, Haddad GG (2003) Calcium influx via L- and Ntype calcium channels activates a transient large-conductance $\mathrm{Ca} 2+$ - activated $\mathrm{K}+$ current in mouse neocortical pyramidal neurons. J Neurosci 23:3639-3648

Syme CA, Gerlach AC, Singh AK, Devor DC (2000) Pharmacological activation of cloned intermediate- and small-conductance $\mathrm{Ca}(2+)$ - activated $\mathrm{K}(+)$ channels. Am J Physiol Cell Physiol 278:C570-C581
Tanaka K, Smith CA (1978) Structure of the chicken's inner ear: SEM and TEM study. Am J Anat 153:251-271

Tucker TR, Fettiplace R (1996) Monitoring calcium in turtle hair cells with a calcium-activated potassium channel. J Physiol 494:613-626

Wissmann R, Bildl W, Neumann H, Rivard AF, Klocker N, Weitz D, Schulte U, Adelman JP, Bentrop D, Fakler B (2002) A helical region in the $\mathrm{C}$ terminus of small-conductance $\mathrm{Ca} 2+-$ activated $\mathrm{K}+$ channels controls assembly with apo-calmodulin. J Biol Chem 277:4558-64

Xia XM, Fakler B, Rivard A, Wayman G, Johnson-Pais T, Keen JE, Ishii T, Hirschberg B, Bond CT, Lutsenko S, Maylie J, Adelman JP (1998) Mechanism of calcium gating in smallconductance calcium-activated potassium channels. Nature 395:503-507

Yoshida N, Shigemoto T, Sugai T, Ohmori H (1994) The role of inositol trisphosphate on ACh-induced outward currents in bullfrog saccular hair cells. Brain Res 644:90-100

Yuhas WA, Fuchs PA (1999) Apamin-sensitive, small-conductance, calcium-activated potassium channels mediate cholinergic inhibition of chick auditory hair cells. J Comp Physiol [A] 185:455-462

Zidanic M, Michael T, Fuchs P (2000) SK2 potassium channel cloned from chick cochlea cDNA. At: Molecular biology of hearing and deafness conference. Bethesda, Maryland, no. 57 